\title{
POR QUE EU NÃO SOU UM PSICÓLOGO COGNITIVISTA: APRESENTAÇÃO PELO TRADUTOR
}

TRANSLATOR'S INTRODUCTION TO WHY I AM NOT A COGNITIVE PSYCHOLOGYST

\author{
Olavo de Faria Galvão
}

UNIVERSIDADE FEDERAL DO PARÁ, BRASIL

\section{RESUMO}

Não é em Skinner (1984) que o behaviorismo radical é fundado, mas essa publicação de Skinner é um exercício, uma lição de behaviorismo radical.

Palavras-chave: Skinner, behaviorismo radical, cognitivismo

\begin{abstract}
Radical behaviorism is not founded in Skinner (1984), but this article is an exercise and a lesson of radical behaviorism.

Key words: Skinner, radical behaviorism, cognitivism
\end{abstract}

$\mathrm{Na}$ década de 70 do século XX floresceu e definiu-se a revolução cultural dos anos 60, que atingiu a expressão científica. $\mathrm{Na}$ distinção entre modos de pensar, as gradações e as sutis diferenças entre elementos incluídos na mesma categoria passaram a ser exploradas, em lugar da afirmação da incompatibilidade entre pólos opostos irreconciliáveis. O dipolo behaviorismocognitivismo, que inicialmente levou os behavioristas a medir o comportamento publicamente observável e os cognitivistas a inferirem construtos metafóricos, começou a ser revisto. "Porque eu não sou um psicólogo cognitivista” é um ensaio em que Skinner inaugura algumas interessantes reinterpretações do comportamento, como a distinção entre ver e saber, e substitui a suposição de que a cognição não existe pela proposição de que a cognição é comportamento, portanto analisável pelas contingências da qual faz parte.

No afã de tornar mais claro o equívoco de uma concepção que admite causas cognitivas para o comportamento, Skinner leva os então (e ainda hoje) empedernidos comportamentistas a analisarem abstrações e sentimentos, assunto tabu, como parte das contingências.

A leitura cuidadosa desse texto recoloca o leitor diante de importantes distinções não usuais envolvidas nos conceitos usados para

Correspondência pelo e-mail ofgalvao@gmail.com 


\section{O. F. GALVÃO}

se falar sobre causas do comportamento. A mas este é um exercício, uma lição de distinção entre cognitivismo e behaviorismo refere-se à questão da causação, e não à acessibilidade do fenômeno. Não é nesse texto que Skinner funda o behaviorismo radical, behaviorismo radical.

Apresentação solicitada pelo Editor Recebido em abril de 2008 